\title{
Snaring a venture capital investment
}

\section{A field guide to biotechnology business plan writing.}

\author{
Michael Lytton
}

One of the questions most frequently asked by entrepreneurs is, "How do you attract the attention of a potential venture capital investor?" The starting point is a good business plan. The bookstores are full of how-to books on writing business plans, although few, if any, are directly helpful on the subject of raising money for a new biotechnology company. Here is a field guide to what works and what doesn't.

Show how the project will make money While most biotechnology business plans go into depth about the technology behind the company, few go to the same effort to explain how this technology will be used to make money. Often, venture capitalists wind up tossing these business plans on the pile of "big science" projects-basic research that is best funded in an academic setting by corporate or government sponsors.

To avoid this fate, you need to spell out your strategy for creating commercial value. If you are a product company, create a timeline that charts out the regulatory and product launch strategy as well as the process of obtaining reimbursement-and then explain how you will get there. If you are a platform company, describe a business model for how your tool or target can generate revenues. In addition, include a strategy for handling the "downsides" of your business model. For example, since databases run the risk of becoming public goods - with consequent low marginsexplain how your business will avoid that trap.

\section{Avoid detailed projections}

Having stated that it is important to demonstrate you can make money, it may seem a direct contradiction to advise that projections of earnings be avoided. However, a swift way to undermine your credibility is to present quarterly or even annual projections of operating results for a biotechnology business not scheduled to earn revenue for some time.

It is far better to focus on identifying who the customers for the product/service will be,

Michael Lytton is a partner and chairman of the technology group at Palmer \& Dodge,

One Beacon Street, Boston, MA 02108-3190

(mlytton@palmerdodge.com).

\section{Funds that receive your executive summary will appreciate knowing that the opportunity you are offering them has not been "shopped around," and are therefore more likely to pay attention.}

how many of them there are, and why the proposed deliverable will address a current need. Let the venture fund do its own projections. If the venture capitalist doing due diligence on your plan wishes to use the power of exponential growth to graphically depict a billion dollar business in a few years, more power to him!

\section{Say what you don't intend to do}

It is important to be realistic about what you can achieve and what must be obtained from corporate partners. Emphasizing what financial and other resources can be obtained cheaply from big pharma will make it easier for venture capitalists to receive the message that a billion dollar opportunity can be accessed through an upfront expenditure of, well, $\$ 50$ million. Although this is a drop in the bucket in relative terms, it is still a lot of money. Far better for most of it to come from a corporate investor who needn't worry about generating a $30 \%$ internal rate of return (IRR) to his limited partners over a three- to fiveyear period, the normal liquidity horizon for venture capitalists.

\section{State upfront who is on the team}

A venture capitalist I know begins his due diligence with one question, "Who is the entrepreneur?" To start with, it's not anyone on the three-page list of scientific advisers, each of whom is involved with multiple companies and has agreed to lend his name to the project in exchange for a grant of stock options. It's not, for the most part, anyone on the board of directors, which is typically populated with such part-time advisers as investment bankers, consultants, attorneys, and other feefor-service providers. The entrepreneur(s) are those people who are committing all or a significant portion of their time to the project.
Whether the business opportunity is in the biotechnology field or elsewhere, venture capitalists uniformly believe that the team is more important than the technology.

\section{Keep it short and send it to the chosen few}

Like all of us, venture capitalists have limited time to focus on a new project. The best way to get their attention is to prepare a two- to threepage nonconfidential executive summary, and send it only to venture capitalists who "qualify."

What should be the criteria for making this short list? First, it must be a fund that is likely to understand the technology. Second, the group must have money to invest: Venture funds run out of money every few years, and then must spend a year or so raising a new fund. Third, they should not have invested in a potential competitor to your business: You don't want to give your future competition a blueprint for success. Fourth, both the fund and the person to whom you send the plan must have industry-wide credibility: Your champion will need to sell the plan internally and to other funds who will form the investing syndicate for your company. Finally, the fund must offer more than money: "Value-added" resources such as contacts with potential corporate partners, access to people who can fill gaps in the management team, and even incubator space at the outset will help your business to grow rapidly.

Funds that receive your executive summary will appreciate knowing that the opportunity you are offering them has not been "shopped around," and are therefore more likely to pay attention. Be prepared to follow up with a full business plan of approximately twenty to thirty pages if they are interested. Detailed due diligence by the venture fund will follow, delving into all relevant aspects of the proposed business opportunity.

\section{Conclusions}

While there is no guarantee that a venture capitalist will invest, a solid, well-written explanation of the business opportunity is the first step to realizing your dreams. Perhaps the best advice for writing this plan is to keep in mind two questions a venture capitalist told me he seeks to answer in reviewing every new opportunity: "Does it work, and who cares?" /// 